\title{
A Trump-elnökség vége - republikánus szemmel
}

\author{
The End of the Trump Presidency - A Republican Viewpoint
}

Jason F. Emert

https://doi.org/10.47707/Kulugyi_Szemle.2021.1.01

Összefoglaló: A 2020-as amerikai elnökválasztás nem várt, sőt az amerikai demokráciától alapvetően idegen fordulatokban is bővelkedett. Az alábbi írás arra tesz kísérletet, hogy a választásokat és 2021 első heteinek a történéseit megfelelő keretbe helyezve értelmezze a Republikánus Párt szemszögéből, majd rátér Donald Trump örökségének a taglalására, illetve a Biden-adminisztráció első lépéseire. Bár a Trump-éra mérlegét sokkal könnyebb lenne megvonni a választások utáni időszak elemzése nélkül, a republikánus szerző szerint az igazságszolgáltatási, a belpolitikai és részben a külpolitikai eredmények az elnök személyétől függetlenül is jelentős republikánus sikernek számítanak. Joe Biden első lépései - bár a korábbi személyi túlkapásokat vélhetően csökkentik - éppen a republikánus szempontból előnyös változásokat fordítják a visszájukra.

Kulcsszavak: Trump, Biden, választás, csalás, külpolitika, Kína, protekcionizmus, NAFTA, legfelsőbb bíróság

Abstract: The US elections of 2020 has featured unexpected events that are uncharacteristic of American democracy. This study aims at giving a framework for the elections and their aftermath from a distinctively Republican angle; then it moves on to see the legacy of Donald Trump and the first steps taken by the Biden Administration. Even though the Republican author claims that the past four years could be assessed much more confidently without the last weeks of the presidency. it is also argued that judicial and domestic developments, as well as some of the foreign policy elements are clearly significant Republican achievements regardless the personality of the president. The first steps of the Biden Administration, however, are obviously aimed at the rollback of these developments that are positive from the Republican angle.

Keywords: Trump, Biden, elections, fraud, foreign policy, China, prolectionism. NAFTA, Supreme Courl

* Fordította: Baranyi Tamás Péter. 


\section{Bevezetés}

Négyévnyi Trump-elnökség után az Amerikai Egyesült Államok új el nököt választott meg és iktatott be Joseph R. Biden Jr. személyében. A hatalomátadás folyamata az USA történelmében eddig ismeretlen, drámai jelenetek kíséretében zajlott, így, sajnos, azokat is értelmez nünk kell a 2020-as elnökválasztás perspektívába helyezéséhez.

A 2020-as amerikai elnökválasztásra úgy kellene emlékeznünk, mint egy teljesen eseménytelen, szabad és tisztességes szavazásra, amelyen 1900 óta a legnagyobb arányban járult a lakosság az urnák elé (1900-ban 73,7\%, 2020-ban 66,3\%). Joe Biden az első elnök, akire több mint 80 millióan szavaztak (Schaul, Rabinowitz és Mellnik, 2020). A voksolás arról is nevezetes lehetne, hogy Biden személyében az Egyesült Államok mindenidők legidősebb elnökjelöltjét választotta meg, akit a választás idején néhány nap választott el a 78. születésnapjától, s ezzel az addigi csúcstartót, Trump elnököt győzte le, aki 2016-ban hetvenéves volt. Az is emlékezetessé tehetné az eseményeket, hogy megválasztották az elsô női alelnököt - a kaliforniai Kamala Harris egyben az első afroamerikai, jamaikai-amerikai és indiai-amerikai is, aki ezt a tisztséget viseli. Ugyanakkor nem ő az első kisebbségi, aki betölti e pozíciót: ez a tisztesség Charles Curtis alelnököt illeti, aki egy kanza törzsbéli indián, és Fehér Toll kanza törzsfőnök ükunokája volt. ${ }^{1}$

A választásokra annak ellenére is republikánus győzelemként kel lene emlékezni, hogy az elnökválasztást a demokraták nyerték meg. Bár az elnökség nyilván befolyásos hivatal, még sincs közvetlen hatással az amerikaiak mindennapi ügyes-bajos dolgaira (vagy legalább is nem kellene, hogy azzal legyen). Az amerikai választók az államok többségében republikánus kormányzókat és állami törvényhozásokat ruháztak fel hatalommal, ez pedig fontos szerepet kap majd, amikor a szövetségi és az állami választási körzetek újrarajzolása 2021-ben megkezdődik. A republikánusok a képviselőházi lemaradásuk jelentős részét lefaragták azzal, hogy több női és kisebbségi jelöltet vettek fel a

Charles Curtis: kansasi republikánus képviselő, majd szenátor, végüil Herbert Hoover alelnöke (1929-1933). 


\section{Külïgyi Szemle}

soraikba. Emellett a párt megnyerte volna a georgiai második fordulós szenátori helyeknek legalább az egyikét, ha nem az elnök és pártbéli szövetségesei viselkedése és csalási narratívája uralja a közvéleményt.

Hozzátartozik a teljes képhez, hogy magam a Republikánus Párt tagjaként már minden szinten vettem részt politikai kampányokban. Még képviselőként is indultam a párt színeiben. Számos párttisztségre megválasztottak, többek között a Fiatal Republikánusok Nemzeti Szövetsége (Young Republican National Federation, YRNF) elnökévé is, ráadásul a szervezet százéves történelme során a legnagyobb többséggel. Fiatal republikánus küildöttként részt vettem a Nemzetközi Fi-

atal Demokrata Unió (International Young Democrat Union, IYDU), a jobbközép ifjúsági szervezetek legnagyobb globális szövetségének a munkájában. Végül egyedüili indulóként választottak meg annak elnökévé - a szervezet első amerikai elnökeként. Mindemellett továbbra is republikánus stratéga, választási jogi szakértő és globális politikai tanácsadó vagyok. Azonban jogászként és a nemzetközi kapcsolatok és a politikatudomány egyetemi oktatójaként az is a feladatom, hogy részrehajlás nélkül értékeljem a Trump-elnökség örökségét.

\section{Az elcsalt válaszás narrativája}

Köztudott, hogy az USA választását nem a közvetlenül leadott népi szavazatok (popular vote) döntik el. Az alapító atyák a föderalizmus és az alulról felfelé épüilő - az egyénnel kezdődő - szuverenitás eszméiben hittek. Így tehát „a november első hétfőjét követő kedden” minden állam választást tart, amelynek során kijelöli az elektorait, akik az elnök- és alelnökjelölt személyére fognak szavazni. A két tisztséget egyszerre választják meg a tizenkettedik alkotmánykiegészités, vagyis 1804 óta (amit a Thomas Jefferson és Charles Pinckney közötti választás előtt hoztak tető alá). Az alkotmány értelmében tehát az elnökeinket és az alelnökeinket egy csoport elektor választja; ők alkotják az Elektori Kollégiumot. Az alkotmány II. cikkelyének első szakasza értelmében ez egy kétlépcsős folyamat: az általános választásoké és az Elektori Kollégiumban lezajló szavazásé. 
Először is minden államnak (és a 23. alkotmánykiegészítés 1961-es ratifikációja óta Columbia Kerületnek is) kötelessége tagokat jelölni az Elektori Kollégiumba. „Minden tagállam a törvényhozó testülete által elóírt módon annyi elektort jelöl ki, amennyi megfelel az állam által a Kongresszusba küildendő szenátorok és képviselők összes számának: szenátort, képviselőt, valamint az Egyesült Államok joghatósága alá tartozó bizalmi vagy hasznot hajtó hivatalt betöltő személyt nem lehet elektorként kijelölni.” A II. cikkely első szakaszának harmadik pontja meghatározza az Elektori Kollégium múködésének a határide jét is: „A Kongresszus megállapíthatja az elektorok megválasztásának idejét és azt a napot, amikor szavazataikat leadják; ez a nap azonos az Egyesült Államok egész területén.” ${ }^{2}$

A kongresszus rendelettel határozza meg azt is, hogy mikor szá molják össze az elektori szavazatokat az államokban, aztán pedig a kongresszus két házában. A rendelet szerint „az elnök és az alelnök elektorai üljenek össze, és minden államban szavazzanak a kijelölé süket követően, a december második szerdája utáni hétfőn, az állami törvényhozás szabályozásának megfelelően”. Ez a nap legutóbb 2020. december 14-re esett.

Az amerikai választójogi törvény megköveteli továbbá, hogy min den állam továbbítsa a kongresszus felé az elektori szavazatokat de cember negyedik szerdájáig, ami ezúttal 2020. december 23. volt. Ekkor - ha minden elektori szavazat beérkezik a megadott időre - a kongresszus két házának együttes ülésén - január 6-án, délután egy órakor - megszámlálják a szavazatokat. Bár Donald Trump elnök felvetette, az Egyesült Államok törvényeiben azonban nyomát sem találni annak, hogy az alelnök, aki a hitelesített szavazatok számlálását felügyeli, bármiféle hatalommal is rendelkezne ahhoz, hogy elfogad jon vagy visszautasítson akárcsak egyetlen voksot is, vagy bármely ál lam szavazatainak a megszámlálását visszatartsa. Ha az Elektori Kol légiumban nem alakul ki egyértelmű többség, akkor a tizenkettedik alkotmánykiegészités értelmében a képviselőház és a szenátus szavaz

2 Az amerikai alkotmány hivatalos fordításának forrása az USA budapesti nagykövetsé gének honlapja (Az Egyesült Államok Nagykövetsége. Budapest, Magyarország, é. n.). 


\section{Külïgyi Szemle}

az elnökről és az alelnökről - a szenátus az alelnök, a képviselőház az elnök személyéról.

Így érkeztünk el a botrányos emlékezetú január 6-i eseményekhez, amikor is a Donald Trump és kampánystábja, valamint jogi csapata által terjesztett, a választások „elcsalásáról” szóló hamis és félrevezető kampány következtében a Trump-rajongók zavargásba kezdtek. Betörtek a Capitolium épületébe, megszentségtelenítették a demokrácia legszentebb szentélyét, és öt ember halálát okozták, köztük a capitoliumi rendôrség egyik tisztjéét, akit egy tűzoltókészülékkel súj tottak halálra (Santora, Specia és Baker, 2021). Donald Trump visel kedése - a választások tisztaságának a tagadása még a legfelsőbb bíróság döntése után is, valamint a tüntető tömeg feltüzelése - indokolhatta az alkotmányos vádindítási eljárást (impeachment) a szó eredeti értelmében és az alapító atyák szellemisége szerint is. Nem ez a groteszk, az amerikai hagyományoktól idegen tömeg volt az elnök utolsó napjaiban terjesztett hamisság egyetlen káros hatása, bár kétségkívüil ez volt a legrosszabb. A Capitolium megtámadása telje sen elhomályosította, hogy a Republikánus Párt elveszítette a Georgia államban folyó második fordulós szenátorválasztásokat, s azzal a szenátusbeli többséget is, ami a következő két évben még nagyobb hatalmat tesz lehetővé a Biden-elnökség számára. Emellett Trump aktuálisan 35, átlagosan 41 százalékos támogatottsággal hagyta el a hivatalát, ami a Gallup-felmérések történetének legalacsonyabb aránya (FiveThirtyEight, 2021). Hogy ezt a számot kontextusba helyezzük, érdemes feleleveníteni, hogy a legutolsó egyciklusos elnök, az idősebb George Bush 56 százalékos támogatottsággal köszönt le hivataláról, az utóbbi elnökök közül Barack Obama 48, George W. Bush pedig 49 százalékos támogatottságot élvezetek nyolcéves hivatalviselés után.

Az elnöknek a választások elcsalásáról és a szisztematikus csalásokról szóló állításai természetesen nem igazak. Valójában maga a Trump-adminisztráció nyilatkozott úgy, hogy „a november 3-i szavazások voltak az amerikai történelem legbiztonságosabb választásai" (Cybersecurity and Infrastructure Security Agency, 2020). A rendszer 
sajátosságaiból adódóan ugyanis csaknem lehetetlen „elcsalni” egy választást. Ahhoz a voksolást felügyelő helyi szereplők százainak, ha nem ezreinek az országos szintű koordinációjára lenne szükség. Emellett a sokat szidott levélszavazatok is biztonságosak, mivel több biztonsági mechanizmust is beépítettek a rendszerbe, ami meggátolja, hogy egy szavazatot többször is meg lehessen számolni. Több olyan állam is van az Egyesült Államokban, amelyben már hosszú évek óta elsósorban - bár nem kizárólag - automatizált levélszavazással bonyolítják le a választást. Ilyen többek között a nagyon konzervatív beállítottságú Utah állam is, amely régóta a Republikánus Párt fellegvára (NPR, 2020).

Választási jogászként és nemzetközi választási megfigyelőként szerzett tapasztalataim alapján tudom, hogy még soha nem volt arra példa, hogy egy jelölt az újraszámlálás következtében meg tudta volna fordítani a szavazás állását, ha olyan sok szavazatra lett volna szüksége, mint amennyi Trumpnak kellett volna a Bidennel szembeni győzelem megszerzéséhez. Ugyanakkor hanyag volnék, ha nem ismer ném el, hogy választási csalás igenis létezik. De nem olyan mértékben, amely megváltoztathatta volna egy vagy több állam választásának az általános eredményét. Ezenkívüil azokon a helyeken, amelyekre Donald Trump kampánya kiemelten fókuszált - Detroit, Philadelphia és Atlanta -, a választási részvétel nem mutatott szignifikáns emelkedést a korábbi évekhez képest (Gabriel, 2020). Valójában némelyikben Trump jobban is szerepelt, mint a legtöbb republikánus jelölt a korábbi választásokon. Az elnök a külvárosokat veszítette el nagy arányban (Garrison, 2020), ezért nem lesz második ciklusa. Az is gyengíti az „elcsalt választás” narratíváját, hogy az állami törvényhozás Michiganben, Pennsylvaniában és Georgiában is republikánus többségű, így ők felelnek a választójogi törvényekért is.

Az elnök és belső körének tagjai gyakran hivatkoztak precedens ként a 2000. évi elnökválasztás jogi hátterére is, ám ebben az abszurd összehasonlításban a történeti ismeretek hiánya egyértelmúen aláásta az érvelésük erejét. George W. Bush akkori kormányzó a választás éjszakáján Floridában ezer szavazattal vezetett Albert 


\section{Külïgyi Szemle}

Gore Jr. alelnökkel szemben. A szűk szavazattöbbség miatt elkerülhe tetlen volt az újraszámlálás, ami Bush előnyét néhány száz szavazatra csökkentette. Ezt követően kézzel is meg kellett számolni a voksokat, s annak eredményeképpen Bush végső szavazattöbbsége 537 szavazatra olvadt. Végüil a legfelsőbb bíróság a „Bush kontra Gore” ügyben az előbbi javára ítélt (Justia. US Supreme Court, 2000). Tehát egy olyan államban, amelyben milliók szavaztak, az újjaszámlálás csak néhány száz szavazatnyit változtatott a választás éjszakáján kialakult összképen, az aznap esti győztes pedig végül megnyerte az államot az újraszámlálás után is. 2020 novemberében viszont Trump több tízezer szavazattal kapott ki számos államban is, így egyáltalán nem hasonlít a 2000-es választáshoz, és az ellenkező sugalmazása nem felel meg a valóságnak. Emellett érdemes felidézni, hogy a 9/11 Bizottság megállapítása szerint a 2000-es választási eredmények bizonytalansága okozta csúszás, valamint az azt követő, elhúzódó hatalomátadási folyamat olyan sérülékenységet okozott, ami hozzájárult a 2001. szeptember 11-i terrortámadás felderítésének elmaradásához (CyberCemetery, 2001). Reméljük, hogy a történelem nem ismétli meg magát amiatt, hogy a Republikánus Párt Trump elnöknek próbált meg segíteni a mentális instabilitása kielégítésében, a nemzetvédelem kétpárti feladatainak a teljesítése helyett.

\section{Donald Trump öröksége}

Sajnos, Trump elnök elsősorban a hivatali ideje utolsó két hónapjáról lesz nevezetes. Ez az időszak mutatta meg, hogy azoknak, akik 2015 óta mondogatták, hogy „a jellem maga a sors”, igazuk lett - és Trumppal a Republikánus Párt sorsa eleve a bukás volt. Nehéz is lenne ezzel vitatkozni, hiszen Donald Trump Herbert Hoover óta az első elnök, aki az újraválasztás helyett a kongresszus mindkét házában addig meglévő többséget is elveszítette egyetlen választás során, továbbá az egyetlen, akit kétszer is alkotmányos vádeljárás alá vontak - teljes joggal. A volt elnököt a szenátusnak felelősségre kellett volna vonnia, és megfosztania az elődjeinek kijáró tisztességektől, illetve el kellett 
volna tiltania a jövőbeli hivatalviseléstől is. Ám mivel a tárgyaláson 57:43 arányban tartották bűnösnek, felmentették a vádak alól (a bűnösség kimondásához kétharmados többségre lett volna szükség).

Trump miatt polgárháborús helyzet alakult ki a Republikánus Pár ton belïl is, amelynek következtében meg kell határozni a párt jövőjének az útját, ami vagy a trumpizmus lesz, vagy a visszatérés a hagyományos jobbközéppártiság irányába. Sok konzervatív érzelmú amerikai nem tudott Trump elnökre szavazni annak jellemhibái és groteszk viselkedése miatt - annak ellenére sem, hogy számos politikai céljával egyetértettek. Én magam sosem tartoztam a párton belüli „Never Trumper"3 táborba, és az elnök politikájának a zömét támogat tam, de közben természetesen más részeit kifogásoltam - főleg azokat, amelyek ellentétben álltak a konzervativizmussal. Trump támogatójaként szálltam versenybe a politikusi állásért, mert ő testesítette meg azokat a jó politikákat is, amelyekben hittem - miközben figyel men kívül hagytam azokat a rossz döntéseit, amelyekkel nem értet tem egyet. Mivel el sem lehetett képzelni a hivatal elnyerését anélkül, hogy az ember szimbolikus értelemben leborult volna Trump előtt, a választóim felé azokat a témákat kellett kidomborítanom, amelyekben szövetségesek voltunk. Bár ez a helyzet sokszor kényelmetlen volt számunkra, a kormányzás felelőssége miatt a republikánusok jelentős része mégis felvállalta. A demokraták és a média el akarják hitetni, hogy minden rossz volt, amit Trump csinált, de ez nem igaz - sőt, néhány dolog kimondottan kiváló volt, bár nagyon kaotikus. Emellett sok olyan embert ismerek, aki becsülettel és elkötelezetten szolgált a Trump-adminisztrációban az amerikai népért - úgyhogy inkább hálásnak és büszkének kell lennünk, hogy élnek köztüink olyanok, akik a mindennapjaink jobbá tételének szentelik az életüket. Mindezek miatt

3 A Never Trump (.Trumpot soha!”) mozgalon 2015 nyarán, a dél-karolinai előválasz tás után alakult azzal a céllal, hogy megakadályozza, hogy Donald Trump republikánus elnökjelölt lehessen. A megszerzett győzelmekkel azonban Trump helyzete biztosnak tủnt, így a mozgalom az elnökjelölő gyúlésen próbálta meg blokkolni a jelölését. A kudarcuk után a mozgalommal azonosított néhány fontos republikánus - Colin Powell korábbi külügyminiszter, Max Boot publicista, illetve a befolyásos neokonzervatív Bill Kristol - ki is lépett a pártból. 


\section{Külïgyi Szemle}

tény, hogy ha nem lett volna az utolsó két hónap, illetve a Covid19-re adott hibás és visszataszító válasz, akkor nem is tartanám a Trump elnökséget olyan kudarcnak, mint amilyennek most érzem.

Összességében milyen is Trump elnök öröksége? Nyilvánvaló, hogy a legnagyobb tette az volt, hogy - minden várakozás ellenére és vert helyzetből - legyőzte Hillary Clintont. Ezért Donald Trump, nem pedig Hillary Clinton nevezhetett ki három bírát a legfelsóbb bíróságba. Így került be a testületbe Neil Gorsuch, Brett Kavanaugh és Amy Coney Barrett. Továbbá Trump elnökségének köszönhetően több mint kétszáz új konzervatív bíró tevékenykedik a szövetségi bíróságokon. Ez önmagában is fontos célja volt a Republikánus Pártnak, és ez képezte az alapját annak az alkunak, amit sok konzervatív kötött, amikor az erkölcsi megfontolásaik ellenére is rá szavaztak. Emellett a Trump által aláírt 2017-es adócsökkentési és munkahelyteremtési törvényre is nagyon nagy szükség volt az amerikai adórendszer kor szerűsítése és a gazdaság felpörgetése érdekében. A jogszabály előse gítette a munkahelyteremtést, vonzotta a beruházókat, visszaterelte a profitot, és bezárt sok gyülöletes kiskaput. Ugyanakkor nem vagyok biztos abban, hogy e nagyszerű eredmények nem pusztán a kongreszszus két házában ülő republikánus képviselők - a szenátusban Mitch McConnell, a képviselőházban pedig Paul Ryan - vezetői kvalitásainak köszönhetők - ez esetben ugyanis tulajdonképpen akármelyik republikánus elnök alatt megvalósultak volna. Azt is el kell ismerni, hogy a Covid19-világjárványra adott válaszok állandóan változtak, és néha egészen értelmetlenek voltak, azonban az adminisztráció, élén Alex Azar egészségügyi miniszterrel - aki gyakran került konfrontációba magával Trumppal is -, kiváló munkát végzett, és a „szakembe rek" jóslatai ellenére gyorsan, az egészségügyi rendszert szükségte lenül komplikálttá tévő miriádnyi bürokratikus szabályozást áthágva eljuttatta a vakcinát az emberekhez. A jelenlegi elosztási nehézségek viszont nagy problémát fognak jelenteni a Biden-adminisztráció szá mára (Weiland, Haberman és Shear, 2020).

Trump elnök végrehajtói hatáskörében - nagyon helyesen - csökkentett számos káros adminisztratív szabályozást, amelyek éveken 
keresztül csak ártottak a gazdaságnak - Biden elnök azonban a rendeleteivel már el is kezdte visszahozni azokat. Azt sem szabad elfe lejteni, hogy három közvetlen elődjétől eltérően Donald Trump - az ôt a külpolitika irányításával megbízó alkotmányos felhatalmazás birtokában és a törvények végrehajtatását előíró kötelezettségeiből eredően - ténylegesen végrehajtotta a jeruzsálemi nagykövetségről szóló 1995-ös törvényt, és hivatalosan is áthelyezte az USA izraeli nagykövetségét Tel-Avivból Jeruzsálembe (Congress.gov, 1995). Ugyanígy igaza volt abban is, hogy kivonta az Egyesült Államokat a párizsi klímaegyezményból és az iráni atomalkuból (Joint Comprehensive Plan of Action, JCPOA) - bár meggyőződésem szerint mind a két szerződést be kellene nyújtani a szenátusnak, hogy az vagy ratifikálja, vagy utasítsa el azokat, ahogy azt az alkotmány előírja. A klímaváltozással szembeni küzdelmet illetően a Trump-adminisztrációnak a nukleáris energiát - az energia legtisztább és legolcsóbb formáját támogató politikája pozitív lépés volt, mind az amerikai fogyasztók, mind a környezetüink szempontjából (Bhambhani, 2020). Végül, de nem utolsósorban, a Trump-elnökségnek a Bahreinnel és az Egyesült Arab Emírségekkel közös erőfeszítése, amelynek eredményeként azok hajlandók normalizálni a kapcsolataikat Izraellel, hihetetlenuil nagy eredmény az egész régió számára. Az is jelentős haladásnak számít, hogy Izrael elismerte Koszovót, habár ennek előkészítését jelentős félreértések és diplomáciai ügyetlenkedések kísérték (Emert, 2020).

Másrészről azonban az Izrael és Marokkó közötti diplomáciai kapcsolatok rendezését célzó, de ïgyetlenül végrehajtott lépések, továbbá a Nyugat-Szahara feletti marokkói szuverenitásnak a nemzet közi jog ellenére történő elismerése, valamint a Szudánra gyakorolt nyomás - egyrészt, hogy a terrorizmust finanszírozó országok listájáról lekerüljön az ország, el kell fogadnia az Izraellel létrehozandó rendezés tervét, másrészt, hogy a nemzetközi segélyekért cserébe fizessen 300 millió dollárt az USA-nak - a politikai döntéshozatal visszataszító formái.

Akadtak egyéb területek is, amelyek kapcsán az elnök jól diagnosztizálta a problémát, de rossz terápiát javasolt. Ezek közül a legfontosabb 


\section{Külïgyi Szemle}

Kína, amely a legjobb esetben fenyegetés, a legrosszabban ellenség. A Trump-kormányzat helyesen tette, hogy Kína viselkedését annak nevezte, ami - többek között az ujgurokkal történteket népirtásnak (Manson, 2021). De a tajvani-amerikai viszony szorosabbra füzése, valamint a magasabb szintủ diplomáciai és katonai kapcsolatok felé tett lépések is a helyes utat jelentik - sôt, úgy látszik, azok a Bidenelnökség alatt is folytatódnak majd (Chang, 2021). A világnak valóban fel kell lépnie a Pekingből érkezỏ ideológia ellen, mielőtt késő lenne. Trump azonban azt hitte, hogy új vámok bevezetésével és a keres kedelmi háború kirobbantásával megváltoztathatja Kína viselkedését. Az utóbbiról még ki is jelentette, hogy az ,jó, és könnyú megnyerni" (Franck, 2018). Ám ez mindeddig nem igazolódott be: a gyáripari munkák nem tértek vissza az Egyesült Államokba, és az ország hanyatlása sem állt meg e téren. Az elnökség idején a gyáriparban tapasztalt bővülés még azelőtt történt, hogy az új vámokat bevezették volna, és azt valójában stagnálás követte, majd a Covid19-járvány hatásaként jelentkező recesszió miatt nagyobb zuhanás történt. Nem lehet eléggé hangsúlyozni, hogy a vámok voltaképpen a fogyasztókra kivetett adókat - és ezért káros és idejétmúlt gazdaságpolitikát - jelentenek. A Wall Street Journalban megjelent riport szerint:

„A Federal Reserve által ágazatonként végzett elemzés szerint a vámok bevezetése valóban növelte a foglalkoztatottságot $0,3 \%$ kal azokban az iparágakban, amelyeket érint a Kínával folytatott kereskedelem, hiszen védelmet biztosított számukra az olcsóbb kínai importtal szemben. Ez a nyereség azonban eltủnt, sőt a visszájára fordult azáltal, hogy a kínai alkatrészek behozatala megdrágult, ami 1,1\%-kal csökkentette a gyáripari foglalkoztatottságot. A jelentés szerint az amerikai importra bevezetett kínai büntetóvámok viszont további $0,7 \%$-kal csökkentették az ame rikai gyáripari foglalkoztatottságot." (Zumbrun és David, 2020)

Így tehát a Trump-féle vámtarifák nettó veszteséget okoztak az amerikai gyáriparnak. Az Egyesült Államok mezőgazdaságát pedig jelentős károk érték a Transz-csendes-óceáni Partnerségből (Trans Pacific Partnership. TPP) való kivonulás miatt - amely egyébként 
az amerikaiak nélkül újra összeállt, ezúttal Átfogó és Előremutató Csendes-óceáni Partnerség (Comprehensive and Progressive Agree ment for Trans-Pacific Parlnership, CPTPP) néven. A TPP elhagyása már a pandémia előtt megnövelte a csődeljárás alá vont farmok számát, és egy több tízmilliárd dolláros mentőcsomagra volt szükség a kereskedelemellenes lépések ellensúlyozására. A lépés ellenére Kína gazdasága 2020-ban is 2,3 százalékkal nôtt, ami azt jelenti, hogy még ebben az évtizedben megelőzheti az Egyesült Államokat, s a világ legnagyobb gazdasága lehet - vagyis korábban, mint ahogy azt jósolták (Cheng, 2021). A Trump-kormányzat politikája tehát csak bátorította és gazdagította Kínát.

Hasonló probléma, hogy Kína erősebben kötődik Európához, mint korábban bármikor - mert az amerikaiak egyszerúen nem tettek lé péseket a legszorosabb szövetségeseik némelyike felé. Sokakat meg lepett, hogy nemrég aláírták az EU és Kína közti befektetési egyez ményt, amely gyengíti az Egyesült Államok befolyását a transzatlanti dimenzióban. Emellett Kína egy sor kereskedelmi szerződést kötött más szövetségeseinkkel is (igy Ausztráliával, Japánnal, Koreával és Új-Zélanddal) a Regionális Átfogó Gazdasági Partnerség (Regional Comprehensive Economic Partnership, RCEP) keretén belül, amely a világ legnagyobb kereskedelmi blokkja lesz - és az Egyesült Államok nem lesz a tagja. Trump elnöknek a szabadkereskedelemmel kapcsolatos ellenérzései miatt az USA gyengébb és kevésbé befolyásos sze replô lesz az ázsiai-csendes-óceáni térségben, mint korábban.

A legfontosabb kereskedelmi megállapodás, amit a kormányzat el tudott érni, az Észak-amerikai Szabadkereskedelmi Egyezmény (North American Free Trade Agreement, NAFTA) frissített válto zata, új nevén az Egyesült Államok-Mexikó-Kanada Egyezmény (United States-Mexico-Canada Agreement, USMCA). Számos tanulmány kimutatja, hogy a szabadkereskedelmi egyezmények, így példá ul a NAFTA, jelentős részét képezik az amerikai gazdasági hegemóniának. Hogy lássuk, milyen fontos szerepet töltött be a NAFTA az érintett országok életében, elegendő arra gondolnunk, hogy 2019-ben rövid időre Mexikó vált az Egyesült Államok legnagyobb kereskedelmi 


\section{Külïgyi Szemle}

partnerévé, mielőtt Kína megelőzte volna. Észak-Amerika gazdaságai szétválaszthatatlanul összefonódtak. Nem jelentkezett a Ross Perot ${ }^{4}$ által 1992-ben jósolt „óriási szívó hang”, amikor a munkahelyek délre özönlöttek. Különösen a Mexikóval folytatott kereskedelem volt hihe tetlenül jótékony az Egyesült Államok számára. A Peterson Nemzet közi Gazdasági Intézet egy 2014-es tanulmánya szerint „minden száz, az amerikai cégek által a mexikói gyáriparban teremtett munkahely re majdnem kétszázötven újonnan létrejött munkahely jutott a cégek amerikai központjában, emellett [összesen] három százalékkal növelték az Egyesüllt Államokban a kutatás-fejlesztésre fordított összegeket" (Hufbauer és Cimino-Isaacs, 2014). Sôt, a National Association of Manufacturers (NAM) állítása szerint az elmúlt negyedszázadban az Amerikában gyártott termékek száma megnégyszereződött, ahogy az alkalmazottak egyre produktívabbá váltak, és többet is kerestek az átlagos amerikai munkabérnél. A NAM emellett úgy számol, hogy az Egyesült Államokban további ötmillió gyáripari munkahelyet kell betölteni a következő tíz évben - tehát az USA még mindig gyáripari vezető hatalom. A NAM azt is megjegyzi, hogy az „észak-amerikai piacok továbbra is létfontosságúak az Egyesült Allamok számára. Valójában Kanada és Mexikó több amerikai gyáripari terméket vásárol az USA-ból (2018-ban összesen 500,3 milliárd dollárnyit), mint az őket követő tizenegy legnagyobb kereskedelmi partnerünk együttvéve" (Massachusetls Institute of Technology, é. n.).

Szűkebb pátriámban, Tennessee államban - ahol Donald Trump 2016-ban és 2020-ban is a szavazatok több mint 60 százalékával nyert - a szabadkereskedelem játszotta a főszerepet a gazdaság fellendülésében. Míg Kanada messze a legnagyobb piac, Mexikó má sodik helyezése is nagyon jelentős, hiszen Tennessee globális exportpiacainak 14 százalékát adja, és több tízezer munkahely függ közvetlenül az oda irányuló exporttól. Ráadásul évről évre fontosabb exportpiaccá válik: Tennessee mexikói kivitele csaknem 250 szá

4 Ross Perot üzletember 1992-ben függetlenként, majd 1996-ban .harmadik párti jelöltként indult az amerikai elnökválasztáson. Bár a kísérletét az egyik legsikeresebb harmadik párti indulásnak tartják. mégsem kapott elektori szavazatokat. 2000 óta a republikánusokat támogatja. 
zalékkal növekedett 2002 óta - ez a trend pedig, úgy tűnik, egyáltalán nem lassul, hacsak nem akasztja meg valami exhibicionista politikai gesztus. Azaz Tennessee exportjának 51 százaléka irányul a USMCA-ben részes partnerországokba. A gyakorlatban Trump kereskedelemellenes politikája leginkább az olyan államokat sújthatta volna, mint Tennessee, ahol egyébként a legnagyobb politikai sikert könyvelhette el - a USMCA létrehozása miatt ez végüil nem történt meg. Habár az egyezmény alig tér el a NAFTA-tól, nagyon fontos új rendelkezéseket tartalmaz a szellemi tulajdonjog védelméról, ez pedig jelentős változás az új digitális gazdaság szempontjából, és számottevő eredmény a szakszervezetek oldaláról - az elfogadását ez utóbbi miatt elsősorban a demokraták és Nancy Pelosi könyvelhették el sikerként (Bryan és Zeballos-Roig, 2019).

Összességében Trump kereskedelempolitikája és az USA Kereskedelmi Főtárgyalójának Hivatala nem az amerikai emberek érdekét szolgálta. Ez különösen azokban az államokban tűnik visszásnak, ahol a szavazók túlnyomórésze az előző elnök mellett tette le a voksát. Azzal, hogy kivonult a TPP-ból, védôvámokat emelt, magára hagyta Európát (mivel nem sikerült létrehozni a TTIP-t, és a globális kereskedelemben a kezdeményezést az ambiciózus Kínára hagyta), Trump miatt az Egyesült Államok a szövetségeseinél kevésbé befolyásossá, a riválisaitól pedig sérülékenyebbé vált. Ez még akkor is így van, ha a TTIP-tárgyalások ellentétei már az Obama-korszakban megjelentek. Még Trump saját koordináta-rendszerében is kudarcosnak számít ez a kereskedelempolitika, hiszen a 2016-os kampány során és a hivatali ideje alatt végig a deficit miatti „kereskedelmi egyensúlyhiányt” kár hoztatta, de éppen ez volt az, ami a kormányzása négy évéből háromban történelmi magasságokba emelkedett - bár a legtöbb szakértő egyetért abban, hogy a kereskedelmi deficit alig számít, és általában az erős gazdaság jellemzője. Sajnos, Trump elnök és erőtlen kereskedelmi tanácsadója, Peter Navarro súlyosan félreértette a nemzetközi 


\section{Külïgyi Szemle}

kereskedelmet, az a meggyőződésük pedig, hogy az Egyesült Álla mokat kihasználják annak során, az egész politikai diskurzust meg fertőzte azokkal a félrevezető információkkal, amelyeket most már mindkét párt használ a politikai haszonszerzés céljából - ez azonban veszélyezteti a jövőbeli szabadkereskedelmi egyezményeket, sőt végső soron a gazdaságunkat is.

Ráadásul Mexikóval kapcsolatban Trump azt hangoztatta, hogy az amerikai nemzetbiztonság érdekében fenn kell tartani a status quót a határ mentén. Bizonyos fokig egyetértek ezzel, és elégedett vagyok a határfal megerősítése melletti kiállással, de őszintének kell lennünk a jelenlegi határválsággal kapcsolatban. Két dolog biztos. Az egyik, hogy az Egyesült Államok bevándorlási rendszere kudarcot vallott, ezért meg kell újítani. Az amerikaiaknak jár a biztonságos határ, ami lehet fal, ahol annak van értelme, vagy digitális megfigyelés, illetve fokozott határőrizet, és több bevándorlási bíróra van szükség, hogy a menedékkérelmi ügyeket gyorsabban el lehessen intézni. Természetesen az nem is kérdés, hogy a gyermekek és szüleik szétválasztásának viszszataszító gyakorlata ebbe nem fér bele. A nyitott határok politikája rossz politika, de a zárt gazdaságé még rosszabb. Azzal biztosíthatjuk a határunkat a leginkább, ha továbbra is szabad és élénk kereskedelmet folytatunk Mexikóval, ami több lehetóséget teremt a legális bevándorlásra - akár ideiglenes vízummal, akár állandó letelepedéssel, illetve az állampolgárság eléréséhez vezető, jól kijelölt úttal. A szabadkereskedelmi egyezmények is a nemzetbiztonság részét képezik.

A Trump-kormányzat fényes teljesítményei közé sorolhatjuk a védelmi és a nemzetbiztonsági stratégiát, amelyek készitését kifejezetten hozzáértő védelmi miniszterek (Mark Esper és James Mattis), illetve nemzetbiztonsági főtanácsadók (H. R. McMaster, John Bolton és Robert O’Brien) irányították. Végüil azonban ezek a területek is magukra vonták az elnök haragját, s megvétózta a 2020-as nemzeti védelmi felhatalmazási törvényt, amit aztán a kongresszus hatalmas többséggel, kétpárti támogatással írt felül. 
Kétségkívïl a kormányzat sikerei közé tartozik még:

- az agresszív és militarista Kína feltartóztatása;

- a terroristák kiiktatása (például Abu Bakr al-Bagdádi ISIS vagy Kászim al-Rimi al-Káida-vezetőé);

- valamint a terrorizmus állami támogatását koordináló szemé lyek likvidálása (például Kászem Szolejmáni iráni tábornoké);

- a NATO-szövetségesek rászorítása arra, hogy 2024-re a nem zeti összterméküik 2 százalékát védelmi kiadásokra fordítsák (ez fontos, bár önkényes lépés volt annak érdekében, hogy mindenki valóban hozzájáruljon a közös védelmi erőfeszitésekhez);

- a koordinált gazdaság-, biztonság-, szabad tengerhajózási, kör nyezet - és energiapolitika révén a Három Tenger Kezdeményezés és az Északi-sarkvidéki Tanács támogatása Kína és Orosz ország feltartóztatásában;

- végül, bár a kivitelezés módjával nem értek egyet, a fokozot tabb amerikai jelenlét Lengyelországban ugyancsak jó mind a nemzetbiztonságunk, mind Európa számára.

Trump elnök védelmi politikájának további öröksége az űrhaderőnem létrehozása (amelynek kezdetei még a 2001. szeptember 11-i tá madások előtti időre nyúlnak vissza, amikor George W. Bush védelmi minisztere, Donald Rumsfeld elnökletével munkához látott az „USA Nemzetbiztonsági Ứrmenedzsment- és Szervezési Felmérő Bizottsága” (Tirpak, 2001). Emellett szorosabb koordináció jött létre az egyes haderőnemek (légierő, szárazföldi erők, parti őrség, tengerészgyalog ság, haditengerészet és űrerő) között, valamint jelentős befektetések történtek a jövendő hadviselési kapacitások és technológiák fejleszté se terén.

Természetesen kudarcok is voltak Trump biztonsági stratégiá jában, főleg a diplomáciai, a katonai és a történelmi tudásában tapasztalható hiányok miatt. A legjellegzetesebb példa erre az észak koreai atomfegyver-mentesítési tárgyalások sorozata volt, hiszen Kim Dzsongun továbbra is nagy hatótávolságú ballisztikus rakétákat teszteltetett, és a Trump-Kim-találkozót követő októberben egy új 


\section{Külïgyi Szemle}

interkontinentális ballisztikus rakétát (ICBM) is felvonultatott a dísz szemlén. A történelmi találkozót a koreai vezető arra használta fel, hogy a nemzetközi tekintélyét növelje, és megszilárdítsa a hatalmát az országában.

Trump Vlagyimir Putyin felé alkalmazott groteszk és engedékeny retorikája nem tartott lépést a kormányzat politikájával, például a „nyitott égbolthoz" vagy a közepes hatótávolságú nukleáris erőkre (INF) vonatkozóhoz hasonló, idejétmúlt szerződésekből való kilépéssel. A legnagyobb hiba azonban az amerikai konzulátusok bezárása volt, s így Moszkva maradt az egyetlen diplomáciai posztunk Oroszországban. Sajnos azonban, úgy tủnik, az új kormányzat sem lesz elég kemény a Kremllel szemben, hiszen Biden elnök már most beleegyezett Putyin kérésébe, hogy meghosszabbítsák az Új START-szerződést.

Végezetüil Trump a kiszámíthatatlan követeléseivel és a haderő kivonással nagyon súlyos hibát követett el a Közel-Keleten is, ami le hetővé tette, hogy Oroszország ismét szerepet játsszon a régióban, valamint megerősítette Törökország és Szíria térségbeli befolyását. Eközben veszélybe sodorta a kurdokat, és feladta az ISIS elleni harc ban elért nyereségeinket, így a terrorszervezet újra felemelkedőben van, annak ellenére is, hogy a különböző alakulataink jelentős sike reket tudhattak magukénak a csapataik megsemmisitésében és a te rületi hatalmuk felszámolásában (2018). Trump elnök negatív öröksé ge - Obama elnökéhez hasonlóan - az ISIS (újra)felemelkedésének a lehetővé tétele is. Ráadásul Trumpnak a katonák hazahozataláról szóló kijelentése nem állja meg a helyét (Giles, 2020), hiszen körülbelül ugyanannyi katonánk állomásozik külföldön, mint Trump előtt, vagyis csak folytatta Obama korlátozott bevetési politikáját. Akárcsak elődje szörnyű drónpolitikáját - sőt, jelentősen meg is emelte a dróntámadások számát (300 százalékkal csak Jemenben!), így még több civil halt meg, és még inkább ellehetetlenült a hírszerzésünk, s ezzel egyre távolabb kerültüink a terror elleni háborúban kitûzött céljainktól (Cupp, 2019). 


\section{A Biden-kormányzat első lépései}

Biden elnök lehetőségei egészen mások most, mint négy évvel ez előtt, amikor távozott a végrehajtói hatalmi ágból. Úgy tűnik, mégis vissza akar térni 2017-hez: visszalépteti az USA-t a párizsi klímaegyezménybe, visszavonja a Keystone Pipeline XL vezeték építési engedélyét, és az iráni atomalkuhoz való visszatérést fontolgatja. Pedig ezek közuil egyik sem az Egyesült Államok gazdasági vagy biztonsági érdeke, és négy év múlva akár mindet vissza lehet fordítani egy-egy elnöki rendelettel. Ugyanakkor, ha akár a párizsi, akár az iráni megállapodás valóban az Egyesült Államok létfontosságú érdeke, akkor azok tervezetét be kellene nyújtania a szenátusnak ratifikációra - ezt azonban nem tette meg, mert mindkettőnek jócskán akadnak ellenzői a saját pártján belüil is.

Számomra a párizsi klímaegyezmény egyszerủ közérzetjavító in tézkedés a nemzetközi vezetők részéról, amellyel azt a látszatot kel tik, hogy csinálnak valamit. Ha komolyan harcolni akarunk a klímaváltozás hatásai ellen, akkor a megszégyenítésen kíviul más módon is felelősségre kellene vonni a renitens szereplőket. A Keystone Pipeline XL engedélyének a visszavonása (amivel megsértjük Kanada érdekeit is), valamint az üvegházhatású gázok kibocsátásának radikális csök kentése, valamint a tiszta energia népszerűsitése érdekében oly fontos repesztéses gázkitermelés megszüintetésének szándéka negatívan fog hatni az energiafüggetlenségünkre. Emellett tény, hogy egy olyan tisztaenergia-napirend, amelynek nem része a nukleáris energia fejlesztése, nem számít komoly energiapolitikának. Az iráni nukleáris alkuhoz való visszatéréssel talán megbékítjuik Európát, ugyanakkor a közel-keleti regionális partnereink (például Bahrein, Izrael, SzaúdArábia és az Egyesült Arab Emírségek) érdekeit sértjüik vele.

Egy másik, korán meghozott elnöki rendelet a szövetségi alkalma zottak kirúgását nehezíti meg. Ez ellenkezik a jó kormányzás elvével, és ha Biden elnök további, szélesebb körú kollektív tárgyalóhatalmat biztosít a szövetségi dolgozók szakszervezeteinek, azzal visszafordítja a Trump-korszakban kialakított áramvonalasabb, számonkérhetőbb 


\section{Külïgyi Szemle}

szövetségi kormányzat pozitív hatását, pedig azt az amerikaiak meg érdemelnék. Emellett az eddiginél több szövetségi szabályozás lehe tővé tétele a munkahelyteremtés és a vállalkozások szabadsága ellen hat. Ha Biden elnök valóban a „normalitáshoz való visszatérés” pártján áll, akkor felhagy az Obama- és a Trump-korszakra jellemző, elnöki rendeleteken nyugvó kormányzással, és úgy éri el a politikai céljait, hogy a kongresszussal együttmúködve olyan törvényeket hoz, ame lyek a sokszínú és megosztott nemzetet képviselik. Nem királyokat és királynóket választunk. A kongresszus hatalmának visszaadása méltó elnöki hagyaték lehetne Joe Biden részéről - bár egyelőre úgy néz ki, hogy nem sieti el a kongresszussal való partneri viszony kialakítását.

Ugyanakkor Biden helyesen teszi, ha elutasítja az „Amerika az első” örökségét, mert annak a következménye valójában inkább az „Amerika egyedül” vagy az „Amerika utoljára” lett. Bár Biden gyakran képviselte a rossz oldalt a külpolitikai vitákban, legalább megérti, hogy Ameriká nak a szabad világ vezető hatalmaként sajátos szerepe van, és a nem zetközi kapcsolatok nagyon fontosak az USA külpolitikai céljainak az elérésében. A külpolitikai csapatát Anthony Blinken külügyminiszter és Jake Sullivan nemzetbiztonsági főtanácsadó vezeti; mindketten tapasztalt és hozzáértő szakemberek, akik jó tanácsokkal fogják ellátni az elnököt, és nem kell attól tartaniuk, hogy a Twitteren kirúgja óket. Úgy gondolom, Biden elnök oda fog figyelni arra, amit mondanak. Blinken küiönösen jelentős előrelépés a korábbi külügyminiszterhez, Mike Pompeóhoz képest, aki a világszínvonalú képzése ellenére is egy, a „bevezetés a politológiába” tantárgyból közepesre vizsgázott diáknak a hozzáállását mutatta a diplomáciával kapcsolatban. Pompeo hozzá nem értését csak Richard Grenell (az USA németországi nagykövete volt 2018 és 2020 között) múlta alul, aki leginkább Twitter-trollként és a legrosszabb diplomáciai képviselőnkként ismeretes. Kétségtelen persze, hogy a Trump-kormányzatban is voltak joggal tisztelt vezető diplomaták, például a USAID korábbi igazgatója, Mark Green vagy a korábbi ENSZ-nagykövet, Nikki Haley, illetve a korábbi moszkvai követ, Jon Huntsman. 
Trump elnökségének immár vége, így Biden elnök alakítja a nemzeti politikát. A demokrata ijesztgetés ellenére Trump némi énközpontú pufogás mellett, de simán távozott: nem volt autoriter vezető, csak alkalmatlan. Trump elnök autoriterként történő jellemzése súlyosan sérti azokat a milliókat, akik ma is autoriter rendszerek kemény elnyomása alatt élnek, és akik nagyon örülnének, ha hozzá hasonló, mértékletes és jó szándékú vezetôjük lenne. Donald Trump nem is volt harcos alkat: valójában a panaszkodók és a politikája áldozatainak pártjává tette a Republikánus Pártot. E kritikához azonban hozzá kell tenni azt is, hogy e szerepeket részben a baloldali médiatúlsúly is generálta, hiszen a Trump-kormányzatnak folyamatos ellenszélben kellett dolgoznia, és már a választási gyózelem óta mindennap a személyét érô súlyos támadásokat kellett kiállnia a végrehajtói hatalomnak. Ennek ellenére a jelenlegi republikánus hozzáállás nem konstruktív, de ez a helyzet remélhetőleg csak átmeneti. Az Egyesült Államok ugyanis még mindig egy határozottan jobbközép beállítottságú ország.

Azonban, sajnos, valószínúbb, hogy a demokraták számára az elnökválasztási győzelem önmagában is az egyre jobban balra tolódó és mindinkább etatista politikájuk igazolását jelenti, és nem veszik majd figyelembe, hogy mindeközben a szavazóurnáknál ez a politika országszerte megbukott. Az elnökválasztás ugyanis kizárólag Trumpról és a sokmilliónyi független szavazóról szólt, akik korábban nem voksoltak, de elegük volt a kaotikus négy évből. Elnökként Joe Bidennek sem lesz könnyủ dolga, ugyanis egy megosztott és sokszínú nemzetet vezet, amelynek a második legnépesebb generációja, a baby boomers tömegesen, tízmilliós nagyságrendben öregszik ki a munkaerőpiacról, és már a hatvanas éveikben lesznek - az ezzel járó egészségi állapotban -, amikor Biden, a "csendes nemzedék" egyetlen tagja, aki elnök lett, leköszön a tisztségéról. Reméljïk, hogy a döntései segítik a

5 Az amerikai szociológiában használt elnevezések szerint az 1901-1927 között születettek greatest vagy G.I. generation (legnagyobb nemzedék vagy közkatona-nemzedék), az 1928-1945-es születésúek a silent generation (csendes nemzedék) vagy lucky few (szerencsés kevesek), az 1946-1964 között világra jöttek pedig a baby boomers (bébibummnemzedék). 


\section{Külïgyi Szemle}

nemzetünkre nehezedő politikai és gazdasági nehézségek leküzdését, és nem csak tovább fokozzák azokat.

Ha az országunk jövője bizonytalan, a Republikánus Párté még in kább az, hiszen a trumpizmus jelensége és a demográfiai folyamatok nem sok jóval kecsegtetnek. A negyven év alattiak túlnyomó többsé ge elutasította Trumpot - valójában ezért is veszített sok szavaza tot a négy évvel ezelőtti voksaihoz képest (Circle, 2020). Azokban az államokban, ahol a választás eredménye nagyon alacsony szavazat küiönbségen múlt, ez a tényező biztosan szerepet játszott a bukásá ban. Ugyanakkor a republikánus oldalon nem sok erőfeszités történt a fiatalok megszólítására azon kívül, hogy a Turning Pointhoz vagy a Students for Trumphoz hasonló szervezetek a szocializmus vádját hangoztatták, és azzal hergelték a liberálisokat. Ennél is aggasztóbb a párt számára, hogy 2024-ben a baby boomer nemzedék már a vá lasztóknak csak alig negyedét fogja kitenni (Brownstein, 2020). Sem mi kétség, Trump elnöksége tönkretette a republikánusok imázsát a fiatalabb amerikaiak körében. Emellett az egymást követő nemzedé kek egyre sokszínúbbé válnak, s végüil a fehér népesség a lakosság nak még a felét sem fogja alkotni. Jelenleg 2045 tünik annak az időpontnak, amikorra az Egyesült Államok kisebbségi többségű országgá (majority-minority nation) válik (Frey, 2018). Tehát minél gyorsabban határolja el magát a párt a trumpizmusról és annak szektaszerű viselkedéséről, annál valószínúbb, hogy képes lesz kinevelni egy új nemze déknyi vezetőt, aktivistát és anyagi támogatót.

A fiatal republikánusok vezetőjeként két éven keresztül folyamatosan, minden beszédemben és minden beszélgetés során felvetettem ezeket a problémákat. Sokan azzal hitegetik magukat, hogy a fiatal szavazók valóban liberálisabbak, de ahogy idősödnek, konzervatívvá válnak (Soltis Anderson, 2018). Ez azonban tévedés - semmilyen statisztikailag sem bizonyítja, hogy ez a jelenség valóban létezne. Ennélfogva akkor kell foglalkoznunk a fiatal szavazókkal, amikor fiatalok - vagy elveszitjük őket örökre. Szerencse, hogy e tekintetben a Demokrata Párt sem szerepel sokkal jobban, úgyhogy még mindig van esély viszszanyerni ezt a réteget. 
Számomra nyilvánvaló, hogy egyik nagy párt sem tett eleget a fiatalokért, miközben az is egyértelmű, hogy az országnak a vezetők új nemzedékére van szüksége, akik nem a hetvenes éveiket tapossák, és értik azokat a problémákat, amelyek az amerikaiak nagy tömegeit sújtják. Ez nem olyan könnyű, mint két ciklusra korlátozni a törvényhozóknak a kongresszusban eltöltött idejét, ${ }^{6}$ ami lusta és alkotmányellenes lépés, ráadásul nem is oldana meg semmit, viszont csökkentené a testület elôtti elszámoltathatóságot. A képviselői mandátumokkal kapcsolatos igazi szabályozást a választások jelentik, és éppen ezért kell komolyan vennünk a szavazópolgárok szerepét a vezetők kiválasz tásában - ezt fogalmazta meg az alapító atya Alexander Hamilton: „Itt, uram, a nép kormányoz."

Viszont sem Biden elnök, sem más politikus nem tudja „meggyó gyítani" az országot, hiába ígéri. A politika a konfliktusok és a nézet küilönbségek színtere, nem az egységé. A nemzet számára azonban politikamentessé kell tenni a mindennapokat, mert annak nem sza badna az élet minden területét átitatnia. Vannak, akik - egészségte len módon - úgy tekintenek a politikára, mint egy vallásra, a politikusokra pedig félistenekként. Az emberekben tudatosulnia kell, hogy az ellenfelük nem az ellenségük, a választott tisztviselőik nem alapvetően korruptak, és a szövetségi kormány, illetve az elnök a legkevésbé fontos kormányzati entitás az életükben. A politikát és a közszolgálatot nemes feladatnak kellene látnunk - ha nem így hisszük, akkor nem is nemes tisztviselőket fogunk választani. Újra fel kell fedeznünk a közösségeinket, és muszáj lesz rájönnünk, hogy az ország meggyógyítása az otthonainkban kezdődik.

1862 decemberében, az amerikai történelem legsötétebb órájában, amikor az ország fennmaradása is bizonytalan volt, Abraham Lincoln elnök a polgárháború dúlása közepette ezt írta a kongresz szusnak: „A szörnyű próbatétel miatt, amelyen keresztülmegyünk - becsületben vagy becstelenségben -, nevünkre az idők végezetéig

6 Ted Cruz texasi és Francis Rooney floridai republikánus szenátor február 1-jén jelentette be, hogy alkotmánykiegészitési javaslatot kívánnak benyújtani, amelynek értelmében a képviselők legfeljebb három kétéves, a szenátorok pedig maximum két hatéves ciklusra vállal hatnának tisztséget. 


\section{Külïgyi Szemle}

emlékezni fognak... Nemes módon megmentjük, vagy dicstelenül elve szejtjük a föld utolsó reménységét." Szerencsére, amit most átélünk, az nem polgárháború, de a kérdés még mindig ugyanaz: megmentjük vagy elveszítjük a föld utolsó reményét. Hiszem, hogy Amerika legjobb napjai még elöttünk vannak, és tudom, hogy túljutottunk már ennél nehezebb korszakokon is, amelyekből mindig még jobban megerősödve kerüiltünk ki. De a világ többi része figyel, és ahhoz, hogy továbbra is nélkülözhetetlen ország maradjunk számára, olyan vezetőkre van szüikség, akik fel tudnak nőni ehhez a feladathoz.

\section{I rodalomjegyzék}

Az Egyesült Államok Nagykövetsége (é. n.). Az Amerikai Egyesült Államok alkotmányáról. A letöltés ideje: 2021. január 31. https:/web.archive. org/web/20160618122348/http://hungarian.hungary.usembassy.gov/ constitution in hungarian.html.

Bhambhani, Dipka (2020). Trump Administration Pivots to Nuclear Energy, Finds Lever Against China, Russia. Forbes. A letöltés ideje: 2021. február 11. https:/www.forbes.com/sites/dipkabhambhani/2020/08/07/trumpadministration-pivots-to-nuclear-energy-finds-lever-against-chinarussia/?sh=56dbf39947bl.

Brownstein, Ronald (2020). The GOP's Demographic Doom. The Allantic. A letöltés ideje: 2021. február 11. https:/www.theatlantic.com/politics/ archive $/ 2020 / 10 /$ millennials-and-gen $-Z^{-}$will-soon-dominate-uselections $/ 616818$.

Bryan, Bob és Zeballos-Roig, Joseph (2019). Trump's New Major Trade Deal Looks a Lot Like NAFTA. Markels Insider. A letöltés ideje: 2021. február 11. https://markets.businessinsider.com/news/stocks/uscanada-mexico-trade-deal-usmca-nafta-details-dairy-auto-disputeresolution-2018-10-1027579947.

Chang, Gordon G. (2021). China Threatens War As Joe Biden Continues the Outreach to Taiwan. The Hill. A letöltés ideje: 2021. február 11. https:// thehill.com/opinion/national-security/535819-china-threatens-war-asjoe-biden-continues-the-outreach-to-taiwan.

Cheng, Jonathan (2021). China Is the Only Major Economy to Report Economic Growth for 2020. The Wall Street Journal. A letöltés ideje: 
2021. február 11. https://www.wsj.com/articles/china-is-the-only-majoreconomy-to-report-economic-growth-for-2020-11610936187.

Circle (2020). Election Week 2020: Young People Increase Turnout, Lead Biden to Victory. A letöltés ideje: 2021. február 11. https://circle.tufts. edu/latest-research/election-week-2020.

Congress.gov (1995). Jerusalem Embassy Act (Public Law 104-45). A letöltés ideje: 2021. február 11. https://www.congress.gov/104/plaws/publ45 PLAW-104publ45.pdf.

Cupp, S. E. (2019). Under Donald Trump, Drone Strikes Far Exceed Obama's Numbers. Chicago Sun Times. A letöltés ideje: 2021. február 11. https:// chicago.suntimes.com/news/2019/5/8/18619206/under-donald-trumpdrone-strikes-far-exceed-obama-s-numbers.

CyberCemelery (2001). The 9/11 Commission Report. A letöltés ideje: 2011. február 11. https:/govinfo.library.unt.edu/911/report/911Report.pdf.

Cybersecurily and Infrastructure Securily Agency (2020). Joint Statement from Elections Infrastructure Government Coordinating Council \& the Election Infrastructure Sector Coordinating Executive Committees. A letöltés ideje: 2021. február 11. https://www.cisa.gov/news/2020/11/12/ joint-statement-elections-infrastructure-government-coordinatingcouncil-election.

Emert, Jason (2020). Kosovo Must Not Settle for a Bad Deal. Prishtina Insight. A letöltés ideje: 2021. február 11. https://prishtinainsight.com/ kosovo-must-not-settle-for-a-bad-deal.

FiveThirlyEighı (2021). 2021 How (un)Popular Is Donald Trump? A letöltés ideje: 2020. február 11. https://projects.fivethirtveight.com/trumpapproval-ratings.

Franck, Thomas (2018). Trump Doubles Down: 'Trade Wars are Good, and Easy to Win'. CNBC. A letöltés ideje: 2021. február 11. https://www.cnbc. com/2018/03/02/trump-trade-wars-are-good-and-easy-to-win.html.

Frey, William H. (2018). The US Will Become 'Minority White' in 2045. Census Projects. Brookings. A letöltés ideje: 2021. február 11. https:/ www.brookings.edu/blog/the-avenue/2018/03/14/the-us-will-becomeminority-white-in-2045-census-projects.

Gabriel, Trip (2020). Even in Defeat, Trump Tightens Grip on State G.O.P. Lawmakers. The New York Times. A letöltés ideje: 2021. február 11. https:/www.nytimes.com/2020/12/09/us/politics/trump-pennsylvaniaelectoral-college.html. 


\section{Külïgyi Szemle}

Garrison, Joey (2020). Trump Baselessly Claims Voter Fraud in Cities, But Suburbs Actually Lost him the Election. USA Today. A letöltés ideje: 2021. február 11. https:/eu.usatoday.com/in-depth/news/politics/ elections/2020/11/13/donald-trump-lost-election-suburbs-not-citiesdespite-claims/6263149002/.

Giles, Christopher (2020). US Election 2020: Has Trump Kept His Promises on the Military? BBC. A letöltés ideje: 2021. február 11. https://www.bbc. com/news/election-us-2020-54060026.

Hufbauer, Clyde G. és Cimino-Isaacs, Cathleen (2014). NAFTA Rejoinder: The US Effects Are Clearly Positive for Most Workers (Part II). Pelerson Institute for International Economics. A letöltés ideje: 2021. február 11. https://www.piie.com/blogs/trade-investment-policy-watch/naftarejoinder-us-effects-are-clearly-positive-most-workers.

Justia (2000). Bush et al. v. Gore et al. Certiorari to the Supreme Court of Florida. A letöltés ideje: 2011. február 11. https:/supreme.justia.com/ cases/federal/us/531/98/case.pdf.

Manson, Katrina (2021). Pompeo Says China's Repression of Uighurs Is 'Genocide'. Financial Times. A letöltés ideje: 2021. február 11. https:// www.ft.com/content/b0d613c6-fa92-48c7-ac3a-aa2614c25e9c.

Massachusells Institule of Technology (é. n.). Manufacturing \& Design. A letöltés ideje: 2021. február 11. https:/manufacturing.mit.edu/careers. NPR (2020). Map: Mail-In Voting Rules by State - And the Deadlines You Need. A letöltés ideje: 2021. február 11. https://www.npr. org/2020/09/14/909338758/map-mail-in-voting-rules-by-state.

Santora, Marc, Specia, Megan és Baker, Mike (2021). Capitol Police Officer Dies from Injuries in Pro-Trump Rampage. The New York Times. A letöltés ideje: 2021. február 11. https://www.nvtimes.com/2021/01/08/ us/brian-sicknick-police-capitol-dies.html.

Schaul, Kevin, Rabinowitz, Kate és Ted Mellnik (2020). 2020 Turnout is the Highest in Over a Century. The Washington Post. A letöltés ideje: 2021. február 11. https://www.washingtonpost.com/graphics/2020/elections/ voter-turnout/.

Soltis Anderson, Kristen (2018). Conservatives Have a Millennial Problem. Washington Examiner. A letöltés ideje: 2021. február 11. https://www. washingtonexaminer.com/weekly-standard/how-conservatives-canfind-a-way-to-appeal-to-millennials. 
Tirpak, John A. (2001). The Space Commission Reports. Air Force. A letöltés ideje: 2021. február 11. https:/www.airforcemag.com/article/0301space/. Weiland, Noah, Haberman, Maggie és Shear, Michael D. (2020). Coronavirus Casts Unwelcome Spotlight on Trump's Health Secretary. The New York Times. A letöltés ideje: 2021. február 11. https://www.nytimes. com/2020/04/29/us/politics/coronavirus-trump-azar.html.

Zumbrun, Josh és David, Bob (2020). China Trade War Didn't Boost U.S. Manufacturing Might. The Wall Sireel Journal. A letöltés ideje: 2021. február 11. https:/www.wsj.com/articles/china-trade-war-didnt-boostu-s-manufacturing-might-11603618203. 